\title{
The Study of Method for Complex Processing Turgay Sub-Standard Aluminum-Containing Raw Materials
}

\author{
G. Sarsenbay, L. A. Myltykbaeva, R. A. Abdulwalyev, S. B. Satylganova \\ Center of Earth Sciences, Metallurgy and Ore Beneficiation, JSC, Science and Education Ministry of the Republic of Kazakhstan \\ Email: ao.cnzmo@rambler.ru
}

Received 2012

\begin{abstract}
objects of the research are Kazakhstan's Turgay clay, studied of method for alumina and potassium metasilicate obtaining from Turgay sub-standard aluminum raw materials. Concluded that optimal conditions for the process of Turgay clay: reaction temperature $100^{\circ} \mathrm{C}$, original solution $\mathrm{K}_{2} \mathrm{O}$ concentration to $300 \mathrm{~g} / \mathrm{dm}^{3}$, reaction time $120 \mathrm{~min}$, liquid-solid ratio of 3:1; optimized the conditions of digestion alumina concentrate: original $\mathrm{Na}_{2} \mathrm{O}$ solution concentration of $400 \mathrm{~g} / \mathrm{dm}^{3}$, temperature $280^{\circ} \mathrm{C}, \mathrm{molar}$ ratio $\mathrm{CaO}: \mathrm{SiO}_{2}=$ 1. Recovery is $99.6 \%$ of alumina digestion under this condition; crystallized solid phase components as $\mathrm{Na}_{2} \mathrm{O} \cdot \mathrm{Al}_{2} \mathrm{O}_{3} \cdot 6 \mathrm{H}_{2} \mathrm{O}$ sodium hydroaluminate crystals. Extracted of alumina from solution of sodium hydroaluminate.
\end{abstract}

Keywords: Potassium Hydroxide Solution; Leaching; Clay; Alumina Concentrate; Sodium Aluminate Solution; Digestion; Desilication; Alumina

\section{Introduction}

With the reduction of bauxite resources, the application of lowgrade aluminum-containing raw materials in aluminum production will be the key question. Kazakhstan is rich of low grade bauxite mine (burnt ash, clay), which were the storage of Turgay clay long enough to provide raw materials for alumina production [1]. For low grade aluminum ore, chemical beneficiation processing - alkali leaching to removal some siliconcontaining to extraction silicate mineral, and alumina production by using concentrate can be comprehensive utilization of raw materials, solve problems of production effectively. Study on alkaline leaching of high-silicon aluminum ore, treated by sodium hydroxide solution and extraction silicate widely visible $[2,3]$, not seen on the potassium hydroxide reports. Potassium silicate as main ingredient for high-quality potassium fertilizer of chloride-free is widely used in agricultural production. For the purpose of this study to complex processing Turgay clay, potassium hydroxide solution used for the first time of low grade aluminum-containing raw materials dressing process, by planning central composite second order rotatable experiment and hydrochemical test, to find the best reaction condition of extraction from Turgay clay industrial alumina and chlorinefree potash fertilizer processing methods.

\section{Experimental}

\subsection{Optimization Process of Clay ore Dressing}

Potassium silicate solution and alumina concentrate can be obtained by baking clay leaching by potassium hydroxide solution, using central composite second order rotatable test [4] to find the optimal leaching conditions.

Chemical composition of Turgay's baking clay samples for experiments is: $\mathrm{SiO}_{2} 37 \%$; $\mathrm{Al}_{2} \mathrm{O}_{3} 42.6 \%$; $\mathrm{Fe}_{2} \mathrm{O}_{3} 13.8 \%$; $\mathrm{CaO}$ $1.3 \% ; \mathrm{Na}_{2} \mathrm{O} 0.8 \%$; other $1.5 \%$; $\mathrm{A} / \mathrm{S}=1.15$. The experiments and results: using of the central composite of second order rotatable to develop test, factors influencing the leaching effect of three is made for the variable: $\mathrm{X} 1$ as the concentration for $\mathrm{K}_{2} \mathrm{O}$ in original solution, $\mathrm{g} / \mathrm{dm}^{3}$; X2 for leaching time, min; X3 for liquid-solid ratio, percentage of $\mathrm{SiO}_{2}$ into solution (y) selected optimization parameter. Experiment conditions and results of Second order rotatable as shown in Table 1.

Table 1 Conditions and results of experiments.

\begin{tabular}{|c|c|c|c|c|c|c|c|}
\hline \multirow{2}{*}{$\mathrm{N}$} & \multicolumn{3}{|c|}{ Conditions, $\mathrm{g} / \mathrm{dm}^{3}$, min } & \multicolumn{4}{|c|}{ Solution components, g/dm ${ }^{3}, \%$} \\
\hline & $\mathrm{X}_{1}$ & $\mathrm{X}_{2}$ & $\mathrm{X}_{3}$ & $\mathrm{~K}_{2} \mathrm{O}$ & $\mathrm{Al}_{2} \mathrm{O}_{3}$ & $\mathrm{SiO}_{2}$ & $\mathrm{SiO}_{2}$ \\
\hline 1 & 100 & 60 & $2: 1$ & 61.1 & 1.38 & 98.0 & 48.21 \\
\hline 2 & 300 & 60 & $2: 1$ & 211.5 & 2.46 & 243.5 & 79.00 \\
\hline 3 & 100 & 180 & $2: 1$ & 56.4 & 1.63 & 99.5 & 48.94 \\
\hline 4 & 300 & 180 & $2: 1$ & 253.8 & 2.89 & 228.5 & 78.40 \\
\hline 5 & 100 & 60 & $4: 1$ & 61.1 & 1.13 & 70.5 & 69.32 \\
\hline 6 & 300 & 60 & $4: 1$ & 282.0 & 2.64 & 105.0 & 79.44 \\
\hline 7 & 100 & 180 & $4: 1$ & 61.1 & 1.63 & 72.5 & 71.29 \\
\hline 8 & 300 & 180 & $4: 1$ & 282.0 & 3.13 & 97.5 & 82.84 \\
\hline 9 & 31.8 & 120 & $3: 1$ & 30.25 & 2.64 & 26.5 & 20.93 \\
\hline 10 & 336.4 & 120 & $3: 1$ & 235.0 & 1.13 & 162.5 & 80.86 \\
\hline 11 & 200 & 19 & $3: 1$ & 188.0 & 1.13 & 95.0 & 65.02 \\
\hline 12 & 200 & 221 & $3: 1$ & 188.0 & 2.64 & 112.0 & 76.66 \\
\hline 13 & 200 & 120 & $1,31: 1$ & 188.0 & 2.64 & 208.0 & 62.26 \\
\hline 14 & 200 & 120 & $4,68: 1$ & 188.0 & 0.12 & 74.0 & 79.06 \\
\hline 15 & 200 & 120 & $3: 1$ & 164.5 & 1.63 & 114.3 & 78.23 \\
\hline 16 & 200 & 120 & $3: 1$ & 188.0 & 1.13 & 114.5 & 78.37 \\
\hline 17 & 200 & 120 & $3: 1$ & 164.5 & 1.13 & 114.0 & 78.03 \\
\hline 18 & 200 & 120 & $3: 1$ & 164.5 & 1.13 & 115.0 & 78.71 \\
\hline 19 & 200 & 120 & $3: 1$ & 164.5 & 1.63 & 113.5 & 77.69 \\
\hline 20 & 200 & 120 & $3: 1$ & 88.0 & 1.63 & 115.3 & 78.88 \\
\hline
\end{tabular}


According to the planning of matrix and experimental results the regression equation calculated, the equation is following:

$$
\begin{aligned}
\mathrm{y}= & 78.14+13.38 \mathrm{X} 1+1.84 \mathrm{X} 2+5.61 \mathrm{X} 3-8.36 \mathrm{X} 12 \\
& -1.30 \mathrm{X} 22-1.36 \mathrm{X} 32-4.83 \mathrm{X} 13
\end{aligned}
$$

Analysis equation can reach the following conclusion: the factors influencing the silica into solution of potassium hydroxide, the action of the concentration of alkali solution mostly strong. And compared to other factors, influence of reaction time on the translate silicon dioxide into solution is weak. Combined effects of three factors are more complex; factor values from 0 to 1 , optimization parameters (y) grows, factor value is higher than the $1, y$ value decreases. Three factors affect the complexity can be interpreted as, dissolution and precipitation of silicon dioxide in the system are two processes occur simultaneously, the result of precipitation forming insoluble compounds - hydro aluminum silicate of potassium. When baking clay samples contact with potassium hydroxide solution, silicon dioxide dissolves faster than the hydrated aluminum silicate, $\beta$ - cristobalite $\left(\right.$ Beta- $\left.\mathrm{SiO}_{2}\right)$ in quartz and silicon into solution, this solution (potassium silicate) as the main ingredient for fertilizer production of potassium is chloride-free. At the same time mullite $\left(3 \mathrm{Al}_{2} \mathrm{O}_{3} \cdot 2 \mathrm{SiO}_{2}\right)$ break down into solution, concentration of alumina in solution at lower relative will exist of aluminum-silicon complexes, where the proportion of aluminium in silicon atoms as a unit, as reaction continues, the complexes with alkali solution combining format insoluble hydrated aluminum silicate of potassium. Experiments concluded that the optimal conditions for the process of Turgay clay: reaction temperature $100^{\circ} \mathrm{C}$, original solution concentration $\mathrm{K}_{2} \mathrm{O} 300$ $\mathrm{g} / \mathrm{dm}^{3}$, reaction time $120 \mathrm{~min}$, liquid-solid ratio of 3:1.

\subsection{Optimization of Process of Digestion Alumina Concentrate in Sodium Aluminum Solution}

The process of extraction alumina products from alumina concentrate carried out by hydrochemical methods [5]. Optimal preparation of alumina under leaching condition concentrate chemical composition as follows: $\mathrm{SiO}_{2} 10.4 \%$; $\mathrm{CaO} 0.2 \% ; \mathrm{K}_{2} \mathrm{O}$ $0.2 \% ; \mathrm{Fe}_{2} \mathrm{O}_{3}$ 9.55\%; $\mathrm{Al}_{2} \mathrm{O}_{3}$ 62.8\%; other 5.0\%; A/S 6.04. Phase compositions are mainly for Mullite and Hematite, with small amounts of hydrated aluminum silicate of potassium, amorphous $\mathrm{SiO}_{2}$ content low, shows many $\mathrm{SiO}_{2}$ in clay in the process is dissolved of solution. Concentrate aluminum oxide digestion in sodium aluminate solution optimizated by hydrochemical process. Test conditions: temperature of $200 \sim 280^{\circ} \mathrm{C}$, time 60 min, original $\mathrm{Na}_{2} \mathrm{O}$ concentration of sodium aluminate solution $330 \sim 450 \mathrm{~g} / \mathrm{dm}^{3}, \mathrm{a}_{\mathrm{k}} 30, \mathrm{CaO}: \mathrm{SiO}_{2}=1.2 \sim 2$. Affect of three factors of temperature, concentration and calcium oxide on the aluminum recovery shown in Figure 1-3.

Figure 1 test results view, increasing temperatures from $200^{\circ} \mathrm{C}$ to $280^{\circ} \mathrm{C}$, percentage of $\mathrm{Al}_{2} \mathrm{O}_{3}$ into sodium aluminate solution accordingly increased from $90.6 \%$ to $97.63 \%$.

Figure 2 test results, when concentration gradually increased to 450 from $330 \mathrm{~g} / \mathrm{dm}^{3}$, the alumina recovery into solution corresponding increased from $89.3 \%$ to $98.56 \%$.

As shown in Figure 3, when the calcium oxide content increased from molar ratio $\mathrm{CaO}: \mathrm{SiO}_{2}=1$ to 2 , alumina recovery solution corresponding decreased from $99.6 \%$ to $94 \%$. Studied the best conditions of digestion: original solution $\mathrm{Na}_{2} \mathrm{O}$ concen- tration of $400 \mathrm{~g} / \mathrm{dm}^{3}$, temperature $280^{\circ} \mathrm{C}$, molar ratio $\mathrm{CaO}$ : $\mathrm{SiO}_{2}=1$. Recovery is $99.6 \%$ of alumina digestion under this condition.

\subsection{Optimization of Process for Desilication of Sodium Aluminate Solution}

The chemical composition of sodium aluminate solution from processing alumina concentrate by hydro chemistry method as follows: $\mathrm{Na}_{2} \mathrm{O} 376.7 \mathrm{~g} / \mathrm{dm}^{3} ; \mathrm{Al}_{2} \mathrm{O}_{3} 65.93 \mathrm{~g} / \mathrm{dm}^{3} ; \mathrm{SiO}_{2} 4.22$ $\mathrm{g} / \mathrm{dm}^{3}, \alpha_{k} 9.4, \alpha_{\mathrm{k}}$ high value of this solution, is not conducive to decomposition out $\mathrm{Al}(\mathrm{OH})_{3}$ from aluminate solution, therefore, needed to be decrease values $\alpha_{k}$ before processing of crystallization. This test uses the crystallization from solution of hydrated sodium aluminate, water soluble crystals method gets the $\alpha_{\mathrm{k}} \sim 1,6$ of sodium aluminate solution. When crystallization, small amounts of $\mathrm{SiO}_{2}$ will affect the crystallization in solution, so before the sodium aluminate hydrate, pre-desilication process of sodium aluminate solution. Take into account the effects of concentration on silicon removal efficiency, $\mathrm{Na}_{2} \mathrm{O}$ dilute solution concentration from $376.6 \mathrm{~g} / \mathrm{dm}^{3}$ to $200 \mathrm{~g} / \mathrm{dm}^{3}$, other components as $\mathrm{Al}_{2} \mathrm{O}_{3} 35 \mathrm{~g} / \mathrm{dm}^{3}$ accordingly, $\mathrm{iO}_{2} 2.2$ $\mathrm{g} / \mathrm{dm}^{3}$.

Calcium oxide for desilication agent, add amount $\mathrm{CaO}: \mathrm{SiO}_{2}$ to $1.5,2$ and 3 calculated, reaction time is $30-180 \mathrm{~min}$, test conducted in the temperature range of $150-250^{\circ} \mathrm{C}$, as shown in Table 2.

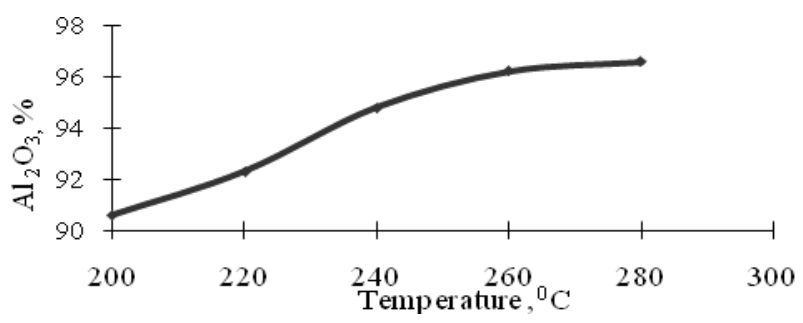

Figure 1. The effect of temperature on the aluminum recovery.

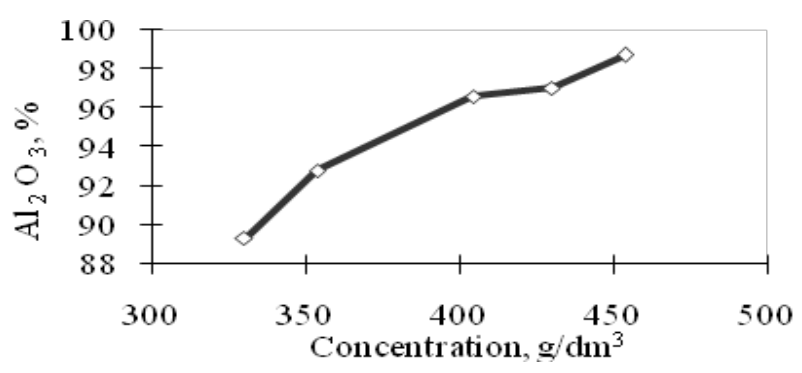

Figure 2. The effect of concentration on the alumina recovery.

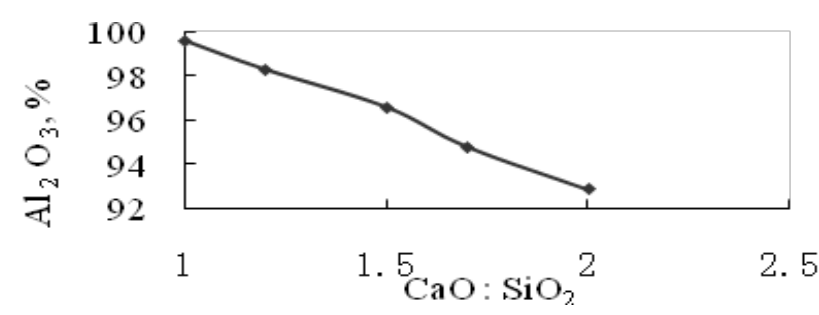

Figure 3. The effect of calcium oxide content on the alumina recov- 
ery.

Test results showed highest conditions of sodium aluminate solution desilication rate: reaction temperature $200{ }^{\circ} \mathrm{C}, \mathrm{CaO}$ added molar ratio $\mathrm{CaO}: \mathrm{SiO}_{2}$ is 3, time for $120 \mathrm{~min}$. Under this condition, sodium aluminate solution desilication rate of $79.5 \%$, solution composition for $\mathrm{Na}_{2} \mathrm{O} 191 \mathrm{~g} / \mathrm{dm}^{3}, \mathrm{Al}_{2} \mathrm{O}_{3} 34 \mathrm{~g} / \mathrm{dm}^{3}$, $\mathrm{SiO}_{2} 0.594 \mathrm{~g} / \mathrm{dm}^{3}, \alpha_{\mathrm{k}} 9,2$.

\subsection{Study on Formation of Alumina from Desilicated Sodium Aluminate Solution}

1) Separating out sodium hydroaluminate crystals from de- silicated sodium aluminate solution

Consists of sodium aluminate solution crystallization of sodium hydroaluminate $-\mathrm{Na}_{2} \mathrm{O} \cdot \mathrm{Al}_{2} \mathrm{O}_{3} \cdot \mathrm{nH}_{2} \mathrm{O}$ test: to evaporation solution concentration of $\mathrm{Na}_{2} \mathrm{O}$ for $500-550 \mathrm{~g} / \mathrm{dm}^{3}$, from which separation crystals. Test results are shown in Table 3. After enrichment to concentrations of $\mathrm{Na}_{2} \mathrm{O} 548 \mathrm{~g} / \mathrm{dm}^{3}$, removal of sodium aluminate solution concentration to concentrations of $\mathrm{Na}_{2} \mathrm{O}$ after $548 \mathrm{~g} / \mathrm{dm}^{3}$, crystallization temperature of $45^{\circ} \mathrm{C}$, under the conditions to quality ratio of 0.05 to join seed crystal, constant stirring. Conditions and results of crystallization shown in Table 3.

Table 2. Experimental conditions and results of desilication of sodium aluminate solution.

\begin{tabular}{|c|c|c|c|c|c|c|c|}
\hline \multirow{2}{*}{$\mathrm{N}$} & \multicolumn{3}{|c|}{ Conditions } & \multicolumn{3}{|c|}{ Components, g/dm3 } & \multirow{2}{*}{$\begin{array}{l}\text { Des. } \\
\text { rate, } \%\end{array}$} \\
\hline & $\mathrm{t},{ }^{\circ} \mathrm{C}$ & $\mathrm{CaO}: \mathrm{SiO}_{2}$ & $\min$ & $\mathrm{Na}_{2} \mathrm{O}$ & $\mathrm{Al}_{2} \mathrm{O}_{3}$ & $\mathrm{SiO}_{2}$ & \\
\hline 1 & 100 & 3 & 120 & 182,4 & 33,7 & 1,93 & 13,4 \\
\hline 2 & 150 & 3 & 120 & 188 & 33,3 & 0,6 & 76,8 \\
\hline 3 & 200 & 3 & 120 & 190,5 & 34 & 0,594 & 79,5 \\
\hline 4 & 250 & 3 & 120 & 196 & 20,1 & 0,65 & 75 \\
\hline 5 & 200 & 1 & 120 & 196 & 30 & 0,747 & 66,7 \\
\hline 6 & 200 & 1,5 & 120 & 190 & 32 & 1,00 & 55,6 \\
\hline 7 & 200 & 2 & 120 & 192 & 33,5 & 0,56 & 75 \\
\hline 8 & 200 & 3 & 120 & 191 & 34 & 0,47 & 79,5 \\
\hline 9 & 200 & 3 & 30 & 196 & 34 & 0,725 & 67,6 \\
\hline 10 & 200 & 3 & 60 & 189 & 33,3 & 0,6 & 77 \\
\hline 11 & 200 & 3 & 120 & 191 & 34 & 0,594 & 79 \\
\hline 12 & 200 & 3 & 180 & 188 & 34 & 0,67 & 69,2 \\
\hline
\end{tabular}

Table 3. Experimental conditions and results of crystallization of sodium hydroaluminate.

\begin{tabular}{|c|c|c|c|c|c|c|c|}
\hline \multirow{2}{*}{$\begin{array}{l}\mathrm{T} \\
{ }^{\circ} \mathrm{C}\end{array}$} & \multirow{2}{*}{$\begin{array}{l}\mathrm{T} \\
\mathrm{h}\end{array}$} & \multicolumn{3}{|c|}{$\begin{array}{l}\text { Test conditions, } \\
\text { composition, g/dm }\end{array}$} & \multicolumn{3}{|c|}{$\begin{array}{c}\text { Test results } \\
\text { composition, } \mathrm{g} / \mathrm{dm}^{3}\end{array}$} \\
\hline & & $\mathrm{Al}_{2} \mathrm{O}_{3}$ & $\mathrm{Na}_{2} \mathrm{O}$ & $\alpha_{k}$ & $\mathrm{Al}_{2} \mathrm{O}_{3}$ & $\mathrm{Na}_{2} \mathrm{O}$ & $\alpha_{\kappa}$ \\
\hline 45 & 10 & 91,89 & 561,1 & 10 & 76,67 & 550,6 & 11,8 \\
\hline 45 & 20 & 91,89 & 561,1 & 10 & 71,44 & 538,5 & 12,4 \\
\hline 45 & 30 & 91,89 & 561,1 & 10 & 31,2 & 527,3 & 27,8 \\
\hline 45 & 40 & 91,89 & 561,1 & 10 & 29,5 & 502,1 & 29,0 \\
\hline
\end{tabular}




\begin{tabular}{llllllll}
\hline 45 & 50 & 91,89 & 561,1 & 10 & 27,33 & 501,8 & 30,2 \\
\hline
\end{tabular}

Crystallization rate test results in mixing continuously when $50 \mathrm{~h}$ reached the highest value. Chemical composition of separated sodium hydroaluminate crystals: $\mathrm{AI}_{2} \mathrm{O}_{3} 25.5 \%$; $\mathrm{Na}_{2} \mathrm{O} 24.1 \%$; other 34.2\%, $\alpha_{\kappa} \quad 1.58$ solid phase components as $\mathrm{Na}_{2} \mathrm{O} \cdot \mathrm{Al}_{2} \mathrm{O}_{3} \cdot 6 \mathrm{H}_{2} \mathrm{O}$, sodium hydroaluminate crystal x-ray diffraction curve as shown in Figure 4.

2) Extraction of aluminum hydroxide from solution of sodium hydroaluminate

Separate sodium hydroaluminate crystal $\alpha_{k}$ is 1.58 , this water-soluble crystals available $\alpha_{k}$ value breaks and crystal decomposition conditions of sodium aluminate solution, from which precipitation $\mathrm{Al}(\mathrm{OH})_{3}$ crystal [6]. Test procedures are as follows: dissolving sodium hydroaluminate crystal

$\mathrm{Na}_{2} \mathrm{O} \cdot \mathrm{Al}_{2} \mathrm{O}_{3} \cdot 6 \mathrm{H}_{2} \mathrm{O}$, get aqueous chemical composition for, $\mathrm{AI}_{2} \mathrm{O}_{3} 100.9 \mathrm{~g} / \mathrm{dm}^{3} ; \mathrm{Na}_{2} \mathrm{O} 98.1 \mathrm{~g} / \mathrm{dm}^{3} ; \alpha_{k}$ is 1.58 , according to the quality of the ratio of 0.3 , to join seed - aluminum hydroxide in water solution, temperature of $62^{\circ} \mathrm{C}-44^{\circ} \mathrm{C}$ conditions, to $70 \mathrm{p} / \mathrm{min}$ speed mixing hydrolysis of sodium aluminate solution to $48 \mathrm{~h}$. According to table4 test findings, when $24 \mathrm{~h}$ reaction, hydrolysis rate of $41 \%$, when $48 \mathrm{~h}$ reaction, hydrolysis rate Increased to 59\%.(Table 4)

After the complete hydrolysis of sodium aluminate solution, the liquid-solid separation are obtained solid aluminum hydroxide, chemical components for $\mathrm{AI}_{2} \mathrm{O}_{3} 61.30 \%, \mathrm{Na}_{2} \mathrm{O} 0.23 \%$, other $35.75 \%$, $\mathrm{X}$ ray diffraction curve shows the solid formation is divided into size 20-50 $\mu \mathrm{m}$ of gibbsite, as shown in Figure 5.

3) preparation of alumina from aluminum hydroxide

From solid aluminum hydroxide under the condition of temperature of $1050^{\circ} \mathrm{C}$, calcined $1 \mathrm{~h}$ we are meeting the criteria of production alumina solid products. Analysis and identification of aluminum oxide crystals derived from chemical composition as: $\mathrm{AI}_{2} \mathrm{O}_{3}$ 98.5\%, $\mathrm{Na}_{2} \mathrm{O} \quad 0.78 \%, \mathrm{SiO}_{2} \quad 0.02 \%, \mathrm{Ti}+\mathrm{V}+\mathrm{Gr}+\mathrm{Mn}$ $0.01 \%$, $\mathrm{ZnO} 0.01 \%, \mathrm{P}_{2} \mathrm{O}_{5} 0.002 \%, \mathrm{Fe}_{2} \mathrm{O}_{3} 0.026 \%$, weight reduction is $1.2 \%$. $\mathrm{X}$-ray diffraction analysis and its solid groups are divided into: $\delta \mathrm{Al}_{2} \mathrm{O}_{3}, \chi \cdot \mathrm{Al}_{2} \mathrm{O}_{3}, \mathrm{Al}_{2} \mathrm{O}_{3}, \theta \mathrm{Al}_{2} \mathrm{O}_{3}, \kappa \mathrm{Al}_{2} \mathrm{O}_{3}$, beta- $\mathrm{Al}_{2} \mathrm{O}_{3}$, as shown in Figure 6.

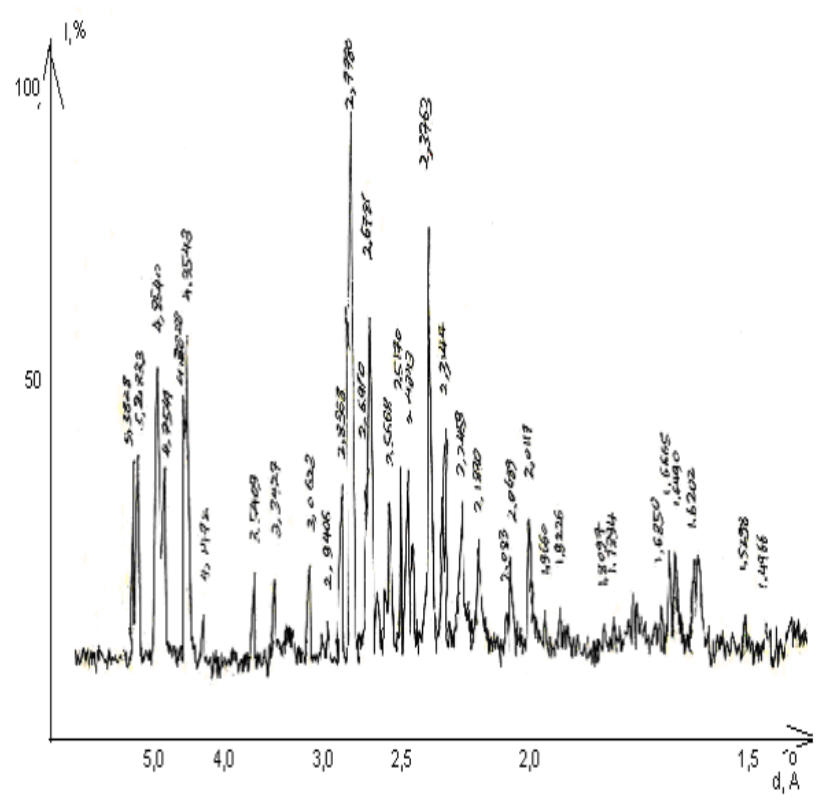

Figure 4. Sodium hydroaluminate crystal $x$-ray diffraction curve. Table 4. Hydrolysis of sodium aluminate solution test results.

\begin{tabular}{|c|c|c|c|c|c|}
\hline \multirow[t]{2}{*}{ Seed content } & \multirow[t]{2}{*}{ Time, h } & \multicolumn{2}{|c|}{$\begin{array}{l}\text { Composition, } \\
\mathrm{g} / \mathrm{dm}^{3}\end{array}$} & \multirow[t]{2}{*}{$\alpha \kappa$} & \multirow{2}{*}{$\begin{array}{c}\text { Hydrolysis } \\
\text { rate, \% }\end{array}$} \\
\hline & & $\mathrm{Na}_{2} \mathrm{O}$ & $\mathrm{AI}_{2} \mathrm{O}_{3}$ & & \\
\hline 0.3 & 24 & 100.3 & 61.5 & 2.75 & 41 \\
\hline 0.3 & 48 & 105.7 & 42.7 & 4.1 & 59 \\
\hline
\end{tabular}

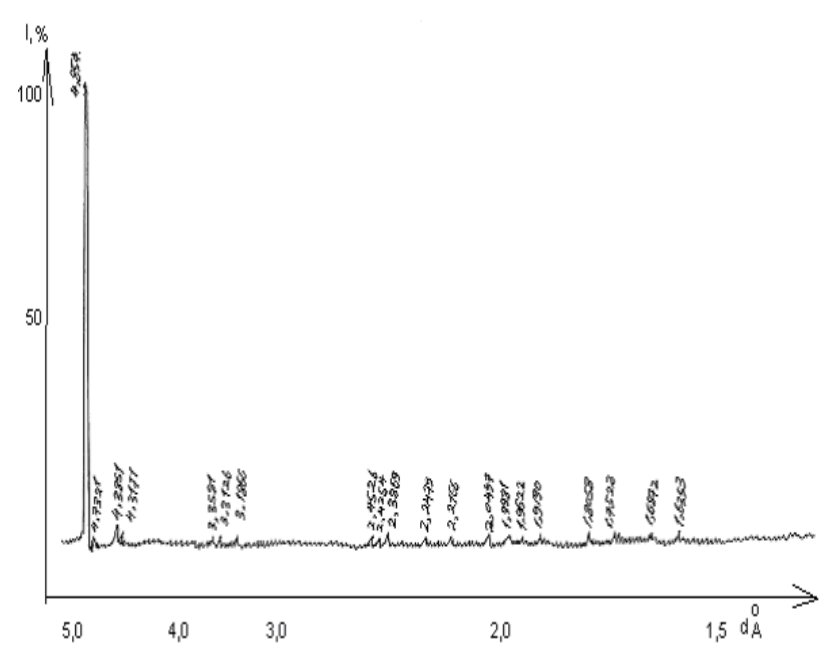

Figure5. Aluminium hydroxide crystals by x-ray diffraction curve. 


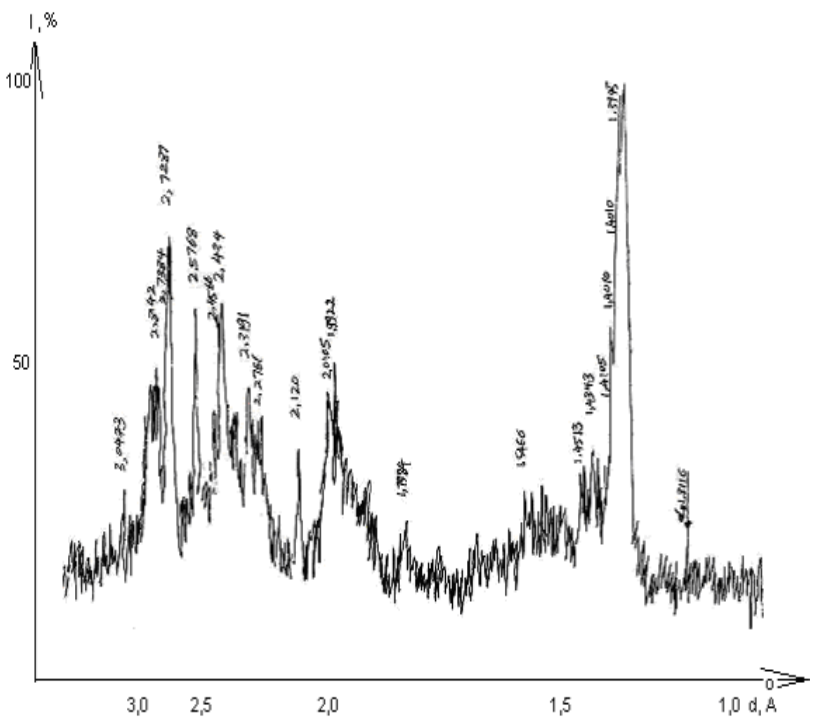

Figure 6 aluminum oxide crystal by x-ray diffraction curve.

\section{Summary}

By research: summary out $\mathrm{KOH}$ solution processing Turgay clay process and sodium aluminate solution digested out alumina concentrate process best reaction conditions; Optimization conditions of dissolving sodium aluminate solution desilication; crystalline solid phase components as $\mathrm{Na}_{2} \mathrm{O} \cdot \mathrm{Al}_{2} \mathrm{O}_{3} \cdot 6 \mathrm{H}_{2} \mathrm{O}$ sodium hydroaluminate crystals; preparation meeting the criteria of production alumina solid products; study for the first time out complex alkaline processing method of clay application of $\mathrm{KOH}$ solution.

\section{REFERENCES}

[1] Kirpal, G.R., (1970) Kaolin clay and allophone from Northern Kazakhstan / / Clay and mineralogy of their properties and practical value. Moscow, pp.226-228.

[2] Suleyeva N.G., Sherban S.A., Tazhibayeva S.H., Romanov L.G., (1982) Study of solubility of ash components of Ekibastuz coal in alkaline // comprehensive utilization of mineral raw materials. № 3, pp. 62-66.

[3] Bukebayev E.T., Nurmagambetov H.N. Investigation of the process of kaolin clay desilication // comprehensive utilization of mineral raw materials, 1982, № 8, pp.28-31.

[4] Nalimov V.V., Chernova N.A. (1965) Statistical methods of planning extreme experiments, Moscow, p. 330.

[5] Ni L.P., Raizman V.L., (1988) Combined methods of processing sub-standard aluminum raw material, Alma-Ata, p. 254. 